\title{
SALING PENGERTIAN ANTAR DIALEK BAHASA KAILI DI LEMBAH PALU
}

\author{
Yunidar Nur
}

Email: yanidarnur@yahoo.co.id

FKIP Universitas Tadulako Palu

Alamat Korepondensi: Kompleks BTN Bumi Roviga Blok A5/19 Tondo Palu 94118

\begin{abstract}
Mutual understanding among dialects is one of the aspects in research of comprehensive sociolinguistic. Assessment of mutual understanding shows how speakers from certain dialect or language society understand other dialect. This study focuses on examination of how far the speakers of four local dialect in Palu valley have interaction. These four dialects are Ledo, Da'a, Unde, and Rai. A sample of 20 people were surveyed representing each of four persons from society leaders, head of families, mothers, teenagers, and children. The results indicate that dialectal speakers of Ledo is $29,7 \%$, Da'a is $37,26 \%$, Unde is $40,14 \%$, and Rai is $31,02 \%$ using Kaili language in various daily association domain. Congeniality to vernacular alone for adult circle is still very high. However younger people have less understanding of which there are about $80 \%$. Difference mutual understanding between dialect interchangeably is not evident as shown by only $10 \%$ of the difference. Thus, it seems that there is good mutual understanding between speakers of four dialects of Kaili's language. Ledo dialect seems to have higher level of understanding, this is not a suprising as Ledo is situated in the middle of the Palu Valley.
\end{abstract}

\section{Keywords}

Dialek, Bahasa Kaili

\section{Pendahuluan}

Saling pengertian antar dialek adalah salah satu aspek dalam penelitian sosiolinguistik yang komprehensif. Penilaian saling pengertian menunjukkan sejauhmana penutur dari suatu dialek, atau masyarakat bahasa mengerti dialek lain. Ahli linguistik menggunakan kriteria saling pengertian untuk membedakan antara dialek dengan bahasa. Adanya saling pengertian antara dua atau lebih masyarakat pemakai bahasa disebut dialek. Sedangkan apabila masyarakat pemakai bahasa itu tidak saling mengerti satu sama lain, maka disebut bahasa (Lehmann, 1973).

Konsep saling pengertian tidak selalu dipergunakan secara konsisten, dan seringkali orang tidak membedakan antara saling pengertian yang inheren dengan saling pengertian kedwibahasaan yang diperoleh melalui proses pembelajaran. Saling pengertian yang sesungguhnya adalah saling pengertian yang inheren, dimana saling pengertian itu berkaitan dengan kekerabatan bahasa atau dialek.

Jika masyarakat bahasa hendak digolongkan sebagai dialek atau bahasa tersendiri atas penilaian saling pengertian, maka penggolongan itu harus didasari atas penilaian saling pengertian yang inheren. Saling pengertian yang inheren didasarkan atas persamaan linguistik diantara dialek-dialek itu, bukan didasarkan atas proses belajar dialek lain.

Bahasa Kaili di Sulawesi Tengah digunakan oleh sebagian penduduk ibukota provinsi, kabupaten Donggala, kabupaten Parimo, dan sebagian kecil di kabupaten Poso. Jumlah penutur bahasa Kaili menurut Sofyan, dkk. (1980) adalah sepertiga dari penduduk Sulawesi Tengah atau lebihkurang 700 ribu orang. Fokus permasalahan penelitian ini adalah; (1) bagaimanakah gambaran penggunaan bahasa Kaili dewasa ini menurut ranah pergaulan sehari-hari?, (2) apakah penutur dialek bahasa Kaili dapat mengerti satu sama lain dengan baik, ataukah mereka mempunyai kesulitan berkomunikasi sehingga harus menggunakan bahasa lain sebagai alternatif?, dan (3) bagaimanakah hubungan saling pengertian antar dialek bahasa Kaili dilihat dari segi jarak letak secara geografis?.

Secara dialektologis dialek-dialek itu berbeda satu sama lain dalam beberapa aspek kebahasaan, khususnya yang menyangkut; perbendaharaan kata, lafal, tata bahasa, cara 
penggunaan, fungsi sosial, dan fungsi seni (Francis, 1983). Para ahli bahasa pada umumnya berpendapat bahwa wilayah atau masyarakat dapat dibagi-bagi dengan mudah ke dalam golongan dialek-dialek tertentu yang memiliki perbatasan yang jelas.

Meskipun demikian, istilah-istilah yang sering dipakai kadang-kadang meragukan. Misalnya, menyebut dialek bahasa Kaili sesuai dengan daerah-daerah tertentu seperti wilayah Lembah Palu, Pedalaman, Pantai Barat, Pantai Timur, Banawa, dan sebagian di Poso. Perbatasan dialek selalu sama dengan perbatasan wilayah-wilayah tersebut. Ketika kita berjalan, kita tidak akan menemukan secara tiba-tiba orang memakai dialek lain yang sangat berbeda, melainkan dialek itu berubah sedikit demi sedikit tanpa terasa. Dialek dapat didefinisikan sebagai variasi bahasa yang sama di mana terjadi saling pengertian. Sedangkan bahasa adalah variasi bahasa yang mempunyai perbedaan yang sangat besar, sehingga antara bahasa yang satu dengan yang lain tidak saling mengerti.

Menurut Grimes dan Grimes (1987) bahasa dapat digolongkan ke dalam; (1) penggolongan bahasa yang mengandung persamaan leksikal adalah $0 \%$ sampai $15 \%$ dapat dipersatukan ke dalam satu filum yang sama, (2) penggolongan bahasa yang mengandung persamaan leksikal 15\% sampai $25 \%$ dapat digolongkan ke dalam satu superstok yang sama, (3) penggolongan bahasa yang mengandung persamaan leksikal 25\% sampai $45 \%$ dapat digolongkan ke dalam satu stok yang sama, (4) penggolongan yang mengandung persamaan leksikal $45 \%$ sampai $60 \%$ dapat digolongkan ke dalam satu rumpun yang sama, (5) penggolongan bahasa yang mengandung persamaan leksikal $60 \%$ sampai $75 \%$ dapat digolongkan ke dalam satu subrumpun yang sama, (6) penggolongan yang mengandung persamaan leksikal $75 \%$ sampai $80 \%$ dapat digolongkan ke dalam bahasa yang berbeda di dalam subrumpun yang sama, dan (7) penggolongan yang mengandung persamaan leksikal $80 \%$ ke atas adalah masyarakat bahasa yang memiliki saling pengertian dari dialek yang berbeda pada bahasa yang sama.

Penilaian saling pengertian antar bahasa bertujuan untuk membedakan antara bahasa dengan dialek. Carl Voegelin dan Zellig Harris menciptakan metode yang dapat menguji kemampuan informan dalam mengerti sebuah teks dari satu dialek terhadap dialek yang lain, dan demikian pula sebaliknya (Voegelin \& Harris, 1978 dalam Shewmaker, 1994).
Penelitian ini menggunakan metode yang pernah digunakan oleh Voegelin dalam penelitian mereka mengenai tujuh dialek bahasa Iroquois di Amerika Utara. Mereka menggunakan dua macam pengujian, yaitu: (1) informan diperdengarkan rekaman teks selama dua menit, kemudian diminta kepada mereka untuk menterjemahkan isi teks tersebut, (2) rekaman teks diperdengarkan lagi selama tiga puluh detik, kemudian diminta untuk menterjemahkan dan hasil pengujian itu dinilai menurut persentase kebenarannya.

Penelitian ini bertujuan untuk menggambarkan; (1) penggunaan bahasa Kaili di dalam pergaulan hidup sehari-hari sebagai bahasa daerah lokal, (2) saling pengertian penggunaan bahasa di antara dialek-dialek bahasa Kaili, (3) penilaian saling pengertian antara dialek-dialek bahasa Kaili, (4) hubungan saling pengertian antara dialek-dialek bahasa Kaili yang dilihat dari segi letak geografis antara satu dengan yang lainnya.

Penelitian ini diharapkan agar dapat bermanfaat baik secara teoretik maupun praktis. Secara teoretik, dapat memperkaya informasi ilmiah tentang kebahasaan di tanah air, khusunya yang berhubungan dengan teori-teori dialektologi dan telaah linguistik historis komparatif. Secara praktis, hasil penelitian ini dapat dijadikan titik tolak dalam pembinaan bahasa-bahasa lokal sebagai bagian dari kebudayaan daerah dan nasional.

\section{Metode}

Penelitian ini dilakukan di kawasan Lembah Palu dengan subjek penelitian adalah komunitas Kaili. Lokasi penelitian meliputi; Besusu, Marawola, Lolitasiburi, dan Tawaeli. Populasi penelitian adalah penutur bahasa Kaili dialek Ledo, Da'a, Unde, dan Rai. Pengambilan sampel menggunakan teknik snowball (lihat: Nasution, 2000). Jumlah sampel yang dijadikan informan sebanyak 20 orang, terdiri dari 4 Tokoh Masyarakat (Tomas), 4 Kepala Rumah Tangga (KRT), 4 Ibu Rumah Tangga (IRT), 4 Remaja (RMJ), dan 4 Anak-anak (ANK).

Pengumpulan data dilakukan melalui penggunaan teks yang memuat cerita tentang pengalaman pribadi orang lain yang berkaitan dengan keadaan hidup sehari-hari sehingga informan dapat memahami dengan muda.

Analisis data penelitian dilakukan menggunakan pendekatan kuantitatif untuk menghitung skor. Sedang pendekatan kualitatif digunakan untuk menilai saling pengertian antar dialek. 


\section{Diskusi dan Temuan}

Keadaan penggunaan bahasa daerah dalam hal ini bahasa Kaili di wilayah Lembah Palu, seperti halnya pada masyarakat bahasa di wilayah lain dipengaruhi oleh faktor-faktor nonkebahasaan atau ekstralinguistik. Faktor-faktor nonkebahasaan yang umum adalah faktor sosial budaya, yaitu latar belakang budaya penduduk setempat yang berasal dari masyarakat bahasa luar. Disamping kehadiran masyarakat bahasa dari luar, hal yang sangat berpengaruh dalam hubungan itu adalah komposisi penduduk. Apabila ada masyarakat bahasa dari luar yang tergolong dominan, maka kecenderungan penggunaan bahasanya atau bahasa alternatif lainnya relatif tinggi. Tetapi, jika tidak terdapat dominasi secara ekstrim, maka penggunaan bahasa Indonesia cenderung tinggi.

Wilayah provinsi Sulawesi Tengah pada umumnya termasuk Lembah Palu, dihuni oleh penduduk atau masyarakat bahasa yang mejemuk. Jika diamati di dalam pergaulan hidup sehari-hari, bahasa yang banyak digunakan penduduk adalah bahasa Indonesia. Gambaran keadaan ini sejalan dengan temuan penelitian terdahulu yang menempatkan Sulawesi Tengah pada peringkat pertama yang tertinggi menggunakan bahasa Indonesia bersama-sama DKI, Maluku, Sulawesi Utara, Riau, dan Kalimantan Timur (Muhadjir dan Lauder, 1992).

\section{Gambaran Penutur Bahasa Kaili Menurut Ranahnya}

Data lapangan yang diperoleh mengenai penggunaan bahasa Kaili sebagai bahasa daerah setempat pada empat wilayah dialek di Lembah Palu, yaitu; dialek Ledo di Besusu (kota Palu), dialek Da'a di Marawola, dialek Unde di Loli Tasiburi, dan dialek Rai di Tawaeli akan dikemukakan berturut-turut. Untuk mengetahui intensitas penggunaan bahasa Kaili digunakan kriteria pengukuran persentase rata-rata; 0-25 = Kadang-kadang, 26-50 = Jarang, 51-75 = Sering, dan 76-100 = Selalu.

\section{Dialek Ledo}

Data mengenai penggunaan bahasa Kaili dialek Ledo di wilayah sampel Besusu yang terletak di dalam kota Palu pada delapan ranah dapat dilihat pada Tabel 1.

Sebanyak delapan ranah yang diteliti pada lima karakteristik informan memperlihatkan bahwa ranah keluarga dan tempat ibadah adalah ranah penggunaan bahasa Kaili dialek Ledo yang tertinggi dengan persentase masing-masing 38\%.
Ranah yang paling rendah penggunaannya adalah tempat hiburan yakni hanya sebanyak $18 \%$. Dilihat dari karakteristik informan, yang tertinggi adalah penutur dari kalangan Tokoh Masyarakat sebanyak 57,5\%. Sedangkan yang paling rendah adalah penutur dari kalangan anak-anak sebanyak 3,8\%. Intensitas penggunaan bahasa Kaili dialek Ledo pada lima karakteristik informan atau jenis penutur untuk delapan ranah rata-rata hanya 29,7\%. Dengan demikian, penggunaan bahasa Kaili dialek Ledo dalam kehidupan sehari-hari tergolong jarang digunakan oleh penuturnya.

Tabel 1: Persentase Penggunaan Bahasa Kaili Menurut Ranahnya pada Penutur Dialek Ledo

\begin{tabular}{|c|c|c|c|c|c|c|}
\hline $\begin{array}{c}\text { Ranah } \\
\text { Penggunaan }\end{array}$ & \multicolumn{5}{|c|}{ Karakteristik Informan } & $\begin{array}{l}\text { Rata- } \\
\text { rata }\end{array}$ \\
\hline Keluarga & 60 & 50 & 45 & 20 & 15 & 38 \\
\hline Tmp badah & 85 & 45 & 40 & 10 & 10 & 38 \\
\hline Pasar & 70 & 50 & 30 & 10 & 0 & 32 \\
\hline Kantor/Sekolah & 40 & 45 & 25 & 0 & 0 & 22 \\
\hline Tmp Hiburan & 25 & 40 & 20 & 5 & 0 & 18 \\
\hline Pesta/Perayaan & 60 & 40 & 30 & 10 & 5 & 29 \\
\hline Tmp Kerja & 70 & 55 & 25 & 15 & 0 & 33 \\
\hline Lain-lain & 50 & 40 & 25 & 20 & 0 & 27 \\
\hline Rata-rata (\%) & 57,5 & 45,6 & 30 & 11,3 & 3,8 & 29,7 \\
\hline
\end{tabular}

\section{Dialek Da'a}

Bahasa Kaili dialek Da'a digunakan oleh penduduk di kecamatan Marawola yang terletak di sebelah selatan kota Palu. Data mengenai penggunaan bahasa tersebut dikemukakan dalam Tabel 2.

Tabel 2: Persentase Penggunaan Bahasa Kaili Menurut Ranahnya pada Penutur Dialek Da'a

\begin{tabular}{|c|c|c|c|c|c|c|}
\hline \multirow{2}{*}{$\begin{array}{c}\text { Ranah } \\
\text { Penggunaan } \\
\text { Bahasa Kaili }\end{array}$} & \multicolumn{5}{|c|}{ Karakteristik Informan } & \multirow{2}{*}{$\begin{array}{l}\text { Rata- } \\
\text { rata } \\
(\%)\end{array}$} \\
\hline & Tomas & KRT & IRT & RMJ & ANK & \\
\hline Keluarga & 75 & 55 & 60 & 30 & 25 & 49 \\
\hline Tmp badah & 90 & 55 & 40 & 20 & 15 & 44 \\
\hline Pasar & 75 & 60 & 40 & 15 & 5 & 39 \\
\hline Kantor/Sekolah & 50 & 40 & 35 & 10 & 5 & 28 \\
\hline Tmp Hiburan & 35 & 45 & 25 & 15 & 5 & 25 \\
\hline Pesta/Perayaan & 70 & 55 & 45 & 20 & 10 & 40 \\
\hline Tmp Kerja & 80 & 70 & 45 & 20 & 10 & 45 \\
\hline Lain-lain & 70 & 60 & 35 & 20 & 15 & 40 \\
\hline Rata (\%) & 68,1 & 55 & 40,6 & 18,8 & 3,8 & 37,26 \\
\hline
\end{tabular}

Ranah penggunaan bahasa Kaili dialek Da'a yang tertinggi adalah ranah keluarga yakni rata-rata sebanyak 49\%, sedangkan yang paling rendah adalah ranah tempat hiburan dengan rata-rata 
hanya $25 \%$. Dari segi karakteristik informan sebagai penutur, yang paling tinggi adalah Tokoh Masyarakat yakni rata-rata sebanyak $68,1 \%$, sedangkan yang paling rendah adalah Anak-anak yakni rata-rata hanya mencapai 3,8\%. Intensitas penggunaan bahasa Kaili dialek Da'a pada lima karakteristik informan atau jenis penutur untuk delapan ranah rata-rata hanya $37,26 \%$. Dengan demikian, penggunaan bahasa Kaili dialek Da'a dalam kehidupan sehari-hari tergolong jarang digunakan oleh penuturnya.

\section{Dialek Unde}

Bahasa Kaili dialek Unde digunakan oleh penduduk yang bermukim di sepanjang pantai sebelah barat Teluk Palu atau sepanjang jalan menuju kota Donggala. Wilayah penelitian untuk dialek Unde ini adalah desa Loli Tasiburi kecamatan Banawa kabupaten Donggala yang berjarak sekitar 25 Kilometer dari kota Palu. Seperti seperti yang telah dikemukakan pada uraian terdepan, intensitas penggunaan bahasa Kaili dialek Unde ini diuraikan berdasarkan karakteristik informan dan ranah penggunaannya. Dari hasil penelitian lapangan yang dilakukan, diperoleh data seperti yang dikemukakan pada Tabel 3.

Tabel 3: Persentase Penggunaan Bahasa Kaili Menurut Ranahnya pada Penutur Dialek Unde

\begin{tabular}{|l|c|c|c|c|c|c|}
\hline \multirow{2}{*}{$\begin{array}{c}\text { Ranah } \\
\text { Penggunaan } \\
\text { Bahasa Kaili }\end{array}$} & \multicolumn{4}{|c|}{ Karakteristik Informan } & Rata- \\
\cline { 2 - 7 } & Tomas & KRT & IRT & RMJ & ANK & (\%) \\
\hline Keluarga & 75 & 60 & 65 & 34 & 25 & 52 \\
\hline Tmp Ibadah & 90 & 55 & 45 & 20 & 20 & 46,2 \\
\hline Pasar & 75 & 65 & 45 & 20 & 10 & 43 \\
\hline Kantor/Sklh & 40 & 45 & 40 & 10 & 5 & 28 \\
\hline Tmp Hiburan & 35 & 45 & 25 & 10 & 5 & 24 \\
\hline Pesta/Pryn & 65 & 60 & 40 & 15 & 15 & 39 \\
\hline Tmp Kerja & 90 & 75 & 50 & 20 & 10 & 49 \\
\hline Lain-lain & 65 & 65 & 45 & 20 & 10 & 45 \\
\hline Rata-rata (\%) & 66,9 & 58,8 & 44,4 & 17,5 & 13,1 & 40,14 \\
\hline
\end{tabular}

Penggunaan bahasa Kaili dialek Unde yang tertinggi adalah pada ranah keluarga dengan angka rata-rata sebanyak 52\%. Sedangkan penggunaan yang paling rendah adalah tempat hiburan dengan rata-rata hanya $24 \%$. Adapun karakteristik informan yang banyak menggunakan bahasa Kaili adalah Tokoh Masayarakat yakni rata-rata sebanyak 66,9\%. Sedangkan yang paling kurang menggunakan adalah informan anak-anak dengan rata-rata hanya sebanyak 13,1\%. Berdasarkan data tersebut, maka intensitas penggunaan bahasa Kaili dialek Unde yang dihitung melalui penggabungan antara delapan ranah dan lima karakteristik informan, diperoleh angka rata-rata sebanyak 40,14\%. Dengan demikian, intensitas penggunaan bahasa Kaili dialek Unde dikategorikan jarang digunakan.

\section{Dialek Rai}

Dialek Rai digunakan oleh penutur bahasa Kaili yang bermukim di wilayah Tawaeli yang berjarak sekitar 20 Kilometer di sebelah utara kota Palu. Data yang diperoleh mengenai penggunaannya berdasarkan ranah dan karakteristik informan dikemukakan pada Tabel 4.

Tabel 4: Persentase Penggunaan Bahasa Kaili Menurut Ranahnya pada Penutur Dialek Rai

\begin{tabular}{|c|c|c|c|c|c|c|}
\hline \multirow{2}{*}{$\begin{array}{c}\text { Ranah } \\
\text { Penggunaan } \\
\text { Bahasa Kaili }\end{array}$} & \multicolumn{5}{|c|}{ Karakteristik Informan } & \multirow{2}{*}{$\begin{array}{l}\text { Rata- } \\
\text { rata } \\
(\%)\end{array}$} \\
\hline & Tomas & KRT & IRT & RMJ & ANK & \\
\hline Keluarga & 65 & 50 & 40 & 25 & 15 & 39 \\
\hline Tempat Ibadah & 85 & 50 & 40 & 15 & 10 & 40 \\
\hline Pasar & 70 & 55 & 35 & 10 & 0 & 34 \\
\hline Kantor/Sekolah & 40 & 40 & 25 & 5 & 0 & 22 \\
\hline $\begin{array}{l}\text { Tempat } \\
\text { Hiburan }\end{array}$ & 35 & 40 & 20 & 0 & 0 & 19 \\
\hline Pesta/Perayaan & 65 & 45 & 25 & 5 & 0 & 28 \\
\hline Tempat Kerja & 80 & 50 & 30 & 10 & 0 & 34 \\
\hline Lain-lain & 70 & 45 & 25 & 15 & 5 & 32 \\
\hline Rata-rata (\%) & 63,8 & 46,9 & 30 & 10,6 & 3,8 & 31,02 \\
\hline
\end{tabular}

Keterangan:

Tomas : Informan Tokoh Masyarakat

KRT : Informan Kepala Rumah Tangga

IRT : Informan Ibu Rumah Tangga

RMJ : Informan Remaja

ANK : Informan Anak-anak (Usia 13-15 Th)

Ranah penggunaan bahasa yang banyak menggunakan bahasa Kaili dialek Rai adalah tempat ibadah dengan persentase rata-rata sebanyak $40 \%$. Sedangkan ranah tempat hiburan adalah ranah yang paling kurang penggunaannya, yakni rata-rata hanya mencapai $19 \%$. Selanjutnya, golongan informan yang paling banyak menggunakan bahasa Kaili dialek Rai adalah Tokoh Masyarakat sebanyak rata-rata $63,8 \%$, dan yang paling kurang menggunakan adalah informan anak-anak yakni rata-rata hanya sebanyak 3,8\%. Kemudian penilaian rata-rata penggunaan bahasa Kaili dialek Rai melalui penggabungan antara ranah dengan karateristik informan hanya mencapai $31,02 \%$. Dengan demikian, intensitas penggunaan bahasa Kaili dialek Rai adalah berkategori jarang. 
Tabel 5: Persentase Penggunaan Bahasa Kaili pada 4 Dialek Menurut Ranah Penggunaannya

\begin{tabular}{|c|c|c|c|c|c|}
\hline \multirow{2}{*}{$\begin{array}{c}\text { Ranah } \\
\text { Penggunaan } \\
\text { Bahasa Kaili }\end{array}$} & \multicolumn{4}{|c|}{ Ragam Dialek } & \multirow{2}{*}{$\begin{array}{c}\text { Rata } \\
(\%)\end{array}$} \\
\hline & Ledo & Da'a & Unde & Rai & \\
\hline Keluarga & 38 & 49 & 52 & 39 & 44,50 \\
\hline Tmp badah & 38 & 44 & 46 & 40 & 32,55 \\
\hline Pasar & 32 & 39 & 43 & 34 & 27,50 \\
\hline Kantor/Seklh & 22 & 28 & 28 & 22 & 25,00 \\
\hline Tmp Hiburan & 18 & 25 & 2 & 19 & 21,50 \\
\hline Pesta/Pryan & 2 & 40 & 39 & 28 & 34,00 \\
\hline Tmp Kerja & 33 & 45 & 49 & 34 & 38,75 \\
\hline Lain-lain & 27 & 40 & 45 & 32 & 36,00 \\
\hline Rata (\%) & 29,7 & 37,26 & 40,14 & 31,02 & 34,53 \\
\hline
\end{tabular}

\section{Saling Pengertian Antar Dialek Bahasa Kaili}

Untuk menggambarkan saling pengertian antar empat dialek secara timbal-balik, maka data-data hasil pengujian teks yang telah disederhanakan disajikan pada tabel 12 di bawah ini.

Tabel 6: Persentase Nilai Rata-rata Saling Pengertian Antar Dialek Bahasa Kaili

\begin{tabular}{|c|c|c|c|c|}
\hline RAGAM DIALEK & LEDO & DA'A & UNDE & RAI \\
\hline Ledo & 95,8 & 93,3 & 94,1 & 95,0 \\
\hline Da'a & 89,3 & 96,8 & 92,4 & 93,7 \\
\hline Unde & 90,1 & 89,7 & 96,4 & 90,3 \\
\hline Rai & 92,6 & 89,1 & 89,2 & 96,5 \\
\hline
\end{tabular}

Angka-angka yang terdistribusi dalam tabel 6 di atas adalah angka persentase rata-rata hasil pengujian teks yang dilakukan secara timbal balik.

Keadaan saling pengertian antar empat dialek dikemukakan sebagai berikut; (1) Penutur dialek Ledo mengerti 93,3\% dialek Da'a, (2) Penutur dialek Da'a mengerti 89,3\% dialek Ledo, (3) Penutur dialek Ledo mengerti 94,1\% dialek Unde, (4) Penutur dialek Unde mengerti 90,1\% dialek Ledo, (5) Penutur dialek Ledo mengerti 95,0\% dialek Rai, (6) Penutur dialek Rai mengerti 92,6\% dialek Ledo, (7) Penutur dialek Da'a mengerti 92,4\% dialek Unde, (8) Penutur dialek Unde mengerti 89,7\% dialek Da'a, dan (9) Penutur dialek Da’a mengerti 93,7\% dialek Rai

Perbedaan saling pengertian antar dialek secara timbal-balik tidak terjadi dengan timpang, karena selisih angkanya tergolong rendah atau tidak ada perbedaan yang mencapai angka 10\%. Dengan demikian, terjadi saling pengertian antar dialek secara normal pada keempat dialek bahasa Kaili.
Saling Pengertian Antar Dialek Bahasa Kaili dari Segi Jarak Letak Geografis

Pertama, Letak geografis penutur dialek Ledo yang berada di posisi simpul tengah di antara dialek-dialek yang lain, diasumsikan sebagai faktor penyebab tingginya pengertiannya terhadap dialek yang lain. Kedua, Pengertian dialek satu terhadap yang lain lebih rendah dibandingkan dialek Ledo terhadap dialek yang lain. Letak dialek-dialek itu jaraknya saling berjauhan dibandingkan dialek Ledo terhadap dialek yang lain.

\section{Penutup}

Penggunaan bahasa Kaili pada delapan ranah dari keempat dialek yang diteliti rata-rata adalah rendah. Penutur mulai jarang menggunakannya. Bahasa pergaulan atau alat untuk berkomunikasi yang paling sering digunakan adalah bahasa Indonesia. Penutur dialek Ledo rata-rata hanya menggunakan bahasa Kaili sebanyak 29\%, Da'a $37,26 \%$, Unde $40,14 \%$, dan Rai $31,02 \%$. Indikasinya adalah informan dewasa sepenuhnya atau $100 \%$ paham atau mengerti bahasa Kaili, sedang informa remaja tidak lagi, dan informan anak-anak yang lebih muda usianya skala pengertiannya juga semakin rendah.

Saling pengertian antara empat dialek bahasa Kaili terjadi dalam taraf yang tinggi yakni ratarata antara $82 \%$ hingga 98\%. Penutur dialek Ledo lebih mengerti dialek Da'a dibandingkan dengan pengertian penutur dialek Da'a tehadap dialek Ledo. Penutur dialek Ledo lebih mengerti dialek Unde dibandingkan dengan pengertian penutur dialek Unde terhadap dialek Ledo. Penutur dialek Ledo lebih mengerti dialek Rai dibandingkan dengan pengertian penutur dialek Rai terhadap dialek Ledo. Penutur dialek Da'a lebih mengerti dialek Unde dibandingkan pengertian penutur dialek Unde terhadap dialek Da'a. Penutur dialek Da'a lebih mengerti dialek Rai dibandingkan dengan pengertian penutur dialek Rai terhadap dialek Da'a. Penutur dialek Unde lebih mengerti dialek Rai dibandingkan dengan pengertian penutur dialek Rai terhadap dialek Unde.

Letak geografis penutur dialek Ledo yang berada di posisi simpul tengah di antara dialek-dialek yang lain, diasumsikan sebagai faktor penyebab tingginya pengertiannya terhadap dialek yang lain. Pengertian dialek satu terhadap yang lain lebih rendah dibandingkan dengan dialek Ledo terhadap dialek yang lain. Letak dialek-dialek itu jaraknya saling berjauhan dibandingkan dialek Ledo terhadap dialek yang lain. 
Bahasa Kaili sebagai salah satu bahasa daerah yang ada di nusantara ini merupakan perwujudan kultural orang Kaili sebagai salah satu etnik yang mempunyai kearifan seperti halnya etnik-etnik yang lain. Tingkat pengertian masyarakat sebagai penutur terhadap bahasa Kaili tergolong masih tinggi, namun penggunaan bahasa tersebut dalam ranah informal sekalipun tampak sangat rendah, lebih-lebih jika dikaitkan dengan faktor umur penuturnya. Keadaan ini bisa menjadi salah satu faktor punahnya bahasa Kaili di masa datang.
Sehubungan dengan hal itu, maka disarankan untuk dilakukan langkah-langkah dalam upaya mempertahankan bahasa Kaili dari kemungkinan punahnya pada suatu ketika. Langkah-langkah tersebut tentu saja diawali oleh pengkajian yang lebih komprehensif, baik dari segi linguistik maupun ekstralinguistik, termasuk bidang kebijakan pemerintah lokal sebagai pihak eksekutif di daerah.

\section{DAFTAR PUSTAKA}

Blair, F. 1990. Survay on Shoestring. Arlington, The Summer Institute of Linguistics and The University of Texas at Arlington, Texas.

Casad, Eugene. 1992. Windows on Bilingualism, The Summer Institute of Linguistics and The University of Texas at Arlington, Texas.

Darjo, Wijoyo S. 1985. Perkembangan Linguistik Indonesia. Jakarta: Arcan.

Francis, W.N. 1983. Dialectology. London: Logman Group Limited.

Friberg, T. 1985. A Dialect Geography of Bugis. Papers in Western Austronesian . Linguistics no. 4.

Grimes, B.F. 1988. The Ethnologue: Linguage of the World. 11 ${ }^{\text {th }}$ Edition. Dallas: Summer Institute of Linguistics.

Grimes, C.E. and B.D Grimes. 1987. Linguage of South Sulawesi. Canberra: Pacific Linguistics Series DNo.78, The Australian Nation University,

Grimes, J.E. 1989. Wedening Sircle of Communication. In Ted Bragman (ed), International Engglish Assessment Confrence, Horsleys Green, England, 24-31 May 1989. Dallas: Summer Institute of Linguistics.

Inghoung A. Sofyan, dkk. 1980. Sistem Morfologi Kata Kerja Bahasa Kaili. Ujung Pandang: Proyek Penelitian Bahasa dan Sastra Indonesia dan Daerah Sulwesi Selatan.

Inghoung A. Sofyan. 1979. Morfologi dan Sintaksis Bahasa Kaili. Ujung Pandang: Proyek Penelitian Bahasa dan Sastra Indonesia dan Daerah Sulawesi Selatan.

Lehmann, W.P. 1973. Historical Linguistics: An Introduction. Second Edition. New York: Holt, Rinehart and Winston.

Masyhuda, M. 1971. Ikhtisar Imbuhan dalam Bahasa Kaili Dialek Palu. Palu: Yayasan Kebudayaan Sulawesi Tengah.

Mills, R. 1979. Proto South Sulawesi and Proto Austronesian Fonology (2 Vols.). Ann Arbor: University Microfilms International.

Muhadjir dan Lauder. 1992. dalam Muhadjir, dkk. (ed). Transformasi Budaya Seperti Tercermin dalam Perkembangan Bahasa-bahasa di Indonesia. Jakarta: Fakultas Sastra Universitas Indonesia.

Nasution, S. 2000. Metode Research. Jakarta: Bumi Aksara.

Ponulele, N.W. 1970. An Analitical Study on The Kaili Language. Skripsi Sarjana. Ujung Pandang: FKSS-IKIP Ujung Pandang. 
Samsuri. 1987. Analisa Bahasa. Jakarta: Erlangga.

Simon, L. 1989. Language Variation and Limit to Communication. Ithaca: DMLL, Cornell University, Reissues by Summer Institute of Linguistics.

Swadesh, M. 1955. Toward Greater Accurancy in Lexicostatistic Dating. International Journal of American Linguistics.

Voegelin, C.F and Z.S Harris. 1978. Method for Determining Intelligibility Among Dialects of Natural Languages. Proceedings of The American Philosophical Society, 95:322-9.

Wolf, H. 1959. Intelligibility and Inter-ethnic Attitudes. Anthropological Linguistics 1(3):34-41. Repriented in Language in Cultur and Society, Edited by Dell Hymes, 1964.pp. 440-5. 